Keywords: DWPF, CPC, sludge, SRAT, Sludge Batch 3, Plutonium

Retention: Permanent

\title{
Supplemental Solubility Data for SRAT Processing of Sludge Batch 3 with H-Canyon Slurry Containing Precipitated Pu and Gd in DWPF
}

C.C. Herman

D.R. Best

Date: November 15, 2002

Westinghouse Savannah River Company

Savannah River Technology Center

Aiken, SC 29808

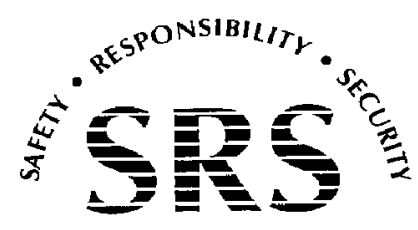

SAVANNAH RIVER SITE

PREPARED FOR THE U.S. DEPARTMENT OF ENERGY UNDER CONTRACT NO. DE-AC09-96SR18500 
This document was prepared in conjunction with work accomplished under Contract No. DE-AC09-96SR18500 with the U. S. Department of Energy.

\section{DISCLAIMER}

This report was prepared as an account of work sponsored by an agency of the United States Government. Neither the United States Government nor any agency thereof, nor any of their employees, makes any warranty, express or implied, or assumes any legal liability or responsibility for the accuracy, completeness, or usefulness of any information, apparatus, product or process disclosed, or represents that its use would not infringe privately owned rights. Reference herein to any specific commercial product, process or service by trade name, trademark, manufacturer, or otherwise does not necessarily constitute or imply its endorsement, recommendation, or favoring by the United States Government or any agency thereof. The views and opinions of authors expressed herein do not necessarily state or reflect those of the United States Government or any agency thereof.

This report has been reproduced directly from the best available copy.

Available for sale to the public, in paper, from: U.S. Department of Commerce, National Technical Information Service, 5285 Port Royal Road, Springfield, VA 22161, phone: (800) 553-6847, fax: (703) 605-6900

email: orders@ntis.fedworld.gov

online ordering: http://www.ntis.gov/help/index.asp

Available electronically at http://www.osti.gov/bridge

Available for a processing fee to U.S. Department of Energy and its contractors, in paper, from: U.S. Department of Energy, Office of Scientific and Technical Information, P.O. Box 62, Oak Ridge, TN 37831-0062,

phone: (865)576-8401,

fax: (865)576-5728

email: $\underline{\text { reports@ adonis.osti.gov }}$ 


\subsection{SUMMARY}

The Savannah River Technology Center (SRTC) was requested to investigate the effects of the addition of Pu and Gd from H-Canyon to Sludge Batch 3 (SB3). The effects on Sludge Receipt and Adjustment Tank (SRAT) processing were discussed in WSRC-TR-2002-00322 [1], which also addressed iron and gadolinium solubility criticality concerns in the presence of sodium oxalate. Since this work was completed, SRTC was requested to provide additional data for solubility testing at higher levels of sodium oxalate. This report supplements WSRC-TR-2002-00322 [1] and addresses testing at higher levels that are considered bounding for DWPF SB3 "sludge-only" processing, as well as "SB3 with Actinide Removal Product" processing.

The specific sodium oxalate levels tested to meet the objective were $75 \%$ and $125 \%$ of the anticipated amount (i.e., 660,000 pounds) of sodium oxalate in Tank 7. Lab-scale SRAT processing was performed at each sodium oxalate level to address the impacts on iron solubility during SRAT processing. The products were then used to study lower $\mathrm{pH}$ effects on iron solubility at the two levels. No surrogates were added for the $\mathrm{Pu}$, since a sufficient surrogate for Pu in the +4 state was not available and was not determined to be necessary based on earlier studies [1].

The solubility measurements during SRAT processing are a subject of this report, whereas, the results of SRAT testing will be discussed in a separate report. The impacts of sodium oxalate on solubility during SRAT processing were as follows:

- Small amounts of iron and gadolinium became soluble with sodium oxalate at $75 \%$ of the amount anticipated in Tank 7 (i.e., $~ 495,000$ pounds). The maximum fraction of iron dissolved was $4.91 \times 10^{-2}(4.91 \%$ of total $\mathrm{Fe})$, while the maximum fraction of gadolinium dissolved was $3.12 \times 10^{-2}(3.12 \%$ of total $\mathrm{Gd})$.

- Although the SRAT process with $125 \%$ sodium oxalate did not meet the nitrite destruction objectives and processing of this level of sodium oxalate would require higher levels of acid addition, iron and gadolinium solubility were calculated based on the data available. The studies reported in WSRC-TR-2002-00322 showed that more iron and gadolinium were dissolved in the lower $\mathrm{pH}$ testing than in SRAT processing. Therefore, the lower $\mathrm{pH}$ testing would be considered more bounding for solubility calculations. For the SRAT run with 125\% of the anticipated amount in Tank 7 (i.e., $~ 825,000$ pounds), a small fraction of iron was again dissolved, 4.37 $\mathrm{x} 10^{-2}$ (4.37\% of total $\mathrm{Fe}$ ). However, all of the gadolinium was dissolved during the SRAT process. The calculated gadolinium results are conservatively high since the gadolinium detected in the SRAT product (i.e., $\sim 0.006 \%$ ) was approximately a fourth of what it was targeted to be based on the amount added (i.e., $~ 0.02 \%$ )

- Soluble iron was similar in the $75 \%$ and $125 \%$ cases and was approximately ten times higher than the $50 \%$ sodium oxalate runs [1]. Soluble Gd, on the other hand, was comparable to the 50\% results for the $75 \%$ sodium oxalate run, but it was much greater for the $125 \%$ run [1].

In the testing to support solubility determinations at $\mathrm{pH}$ levels below those expected in typical SRAT processing (i.e., $2<\mathrm{pH}<4$ ), the following was observed:

- Higher levels of the available iron and gadolinium became soluble. In the lower $\mathrm{pH}$ testing, up to $9.75 \%$ iron and $56.2 \%$ gadolinium were dissolved from the SRAT product with $75 \%$ of the anticipated sodium oxalate, while up to $15.68 \%$ iron and $100 \%$ gadolinium were dissolved from the SRAT product containing $125 \%$ of the anticipated sodium oxalate. Therefore, $\sim 90 \%$ of the iron and $\sim 44 \%$ of the gadolinium remained insoluble in testing with $75 \%$ sodium oxalate, while $\sim 84 \%$ of the iron and no gadolinium remained insoluble for the testing with $125 \%$ sodium oxalate. The gadolinium results for the $125 \%$ test have the same caveat as the SRAT tests since the same gadolinium number for the SRAT product was used to perform the calculation.

- Soluble iron was higher in both the $75 \%$ and $125 \%$ cases compared to the $50 \%$ and no sodium oxalate cases previously reported [1]. Soluble gadolinium for the $75 \%$ case was comparable to the $50 \%$ case data, while the $125 \%$ case had much higher soluble gadolinium [1].

\subsection{INTRODUCTION AND BACKGROUND}

Currently, DWPF is operating using a sludge-only processing flowsheet. Sludge Batch 2 (SB2) was being fed to the DWPF before the current outage. The next batch to be qualified for DWPF processing is SB3. For each sludge batch, SRTC has performed non-radioactive and radioactive sludge runs to evaluate potential chemical processing issues. SRTC has been and is performing studies to evaluate processing of SB3. Sludge Batch 3 is primarily Tank 7 sludge, but is expected to contain several components that are considered non-typical to DWPF sludge and also higher levels of 
noble metals than previously processed sludge batches. In addition to the Tank 7 contents, an H-Canyon slurry containing precipitated $\mathrm{Pu}$ with $\mathrm{Gd}$ has already been transferred to Tank 51 to be fed as part of SB3 and it has been proposed to add Tank 18, Tank 19, and $\mathrm{Am} / \mathrm{Cm}$ feed. The studies discussed in this report concentrate on the effects of high levels of sodium oxalate when combined with the H-Canyon slurry in the SRAT. Preliminary information on SRAT processing with the sodium oxalate and the H-Canyon slurry, as well as some of the effects of the other nontypical components of Tank 7 (sand and coal), have already been reported [(1), (2), and (3)]. The data in this report supplement the data reported in WSRC-TR-2002-00322 [1] by testing the effects of higher levels of sodium oxalate on iron solubility. The supplemental data in this report was performed under the guidance of WSRC-RP-2002-00320 [4].

Historical information indicates that Tank 7 may contain sodium oxalate at levels up to 660,000 pounds [5]. This level is much higher than other tanks processed in the DWPF, therefore its impacts on processing have to be fully understood or researched before it can be processed. Issues related to criticality are of utmost concern with regards to the ability to process the $\mathrm{H}$-Canyon precipitated slurry since it is believed that the oxalate may solubilize iron contained in SB3 to the tris-oxalato ion, $\mathrm{Fe}\left(\mathrm{C}_{2} \mathrm{O}_{4}\right)_{3}{ }^{3-}$. Since iron is considered the primary neutron poison in the DWPF feed and is normally present in the sludge solids, any impacts on its behavior due to the presence of the sodium oxalate must be understood before SB3 can be processed in DWPF. Initial results of studies performed to address these issues have been reported [(1) and (2)], but SRTC was requested by DWPF to perform additional studies at higher sodium oxalate levels to help address criticality concerns. The two levels of sodium oxalate selected were $75 \%$ and $125 \%$ of the anticipated amounts in Tank 7. These values correspond to 495,000 and 825,000 pounds of sodium oxalate in Tank 7 . It is anticipated that these two levels will bound SB3 processing and SB3 processing with the addition of the Actinide Removal Product (if no washing of Tank 7 sludge is performed).

\subsection{EXPERIMENTAL}

The testing was performed at the Aiken County Technology Laboratory (ACTL) using the same configuration as earlier testing (see reference [1] for details). In summary, the equipment consisted of a four-liter kettle to replicate the SRAT, the SRAT Condenser, the Formic Acid Vent Condenser, the Mercury Water Wash Tank, and the Slurry Mix Evaporator Condensate Tank (SMECT). Run plans were written for each SRAT test to provide operational guidance and trim chemical and acid addition amounts [(6) and (7)].

The same simulated sludge as used in earlier studies was used in this testing. The sludge was made for processing of SB2 and is representative of Tank 8 material. The composition of the Tank 8 surrogate and the projected SB3 compositions [8] are given in Table 1. The composition of the Tank 8 simulant did not exactly match the composition of the projected SB3 sludge; however, the small deviations in composition were expected to have minimal impact on processing with regards to the $\mathrm{Pu} / \mathrm{Gd}$ precipitate.

To closer match the anticipated components of the SB3 sludge, sand, coal, mercury, noble metals, and Gd were added to the Tank 8 simulant. On a dried sludge solids basis (free of any sodium oxalate additions), sand was added at $1.12 \mathrm{wt} \%$ and coal was added at $0.72 \mathrm{wt} \%$ [8]. Both the sand and coal were received from the manufacturer of the sand filter material that was transferred to Tank 7 and were of the specification particle size. Mercury was added at the anticipated level of $0.076 \mathrm{wt} \%$ (dried solids basis) [8]. Noble metals were added at two different levels during the runs. The run with $75 \%$ sodium oxalate contained $10 \%$ of the nominal anticipated amount, while the run with $125 \%$ sodium oxalate contained the nominal anticipated amount of noble metals [8]. The reason for the difference was that the $75 \%$ sodium oxalate SRAT product with low noble metals was readily available for additional testing. The noble metals level should not have a significant impact on the solubility of the Fe and $\mathrm{Gd}$. Gd was added to the sludge at $0.037 \mathrm{wt} \%$ to represent the Gd contribution from the H-Canyon slurry.

As mentioned above, two levels of sodium oxalate were used in the testing. For each SRAT run, sodium oxalate was blended with the sludge in the necessary amounts. Again, the basis amounts used were 495,000 or 825,000 pounds of sodium oxalate remaining. 
Table 1 - Sludge Compositions (Wt\% Calcined Basis with Calcine Factor of 0.80)

\begin{tabular}{|c|c|c|}
\hline Element & $\begin{array}{c}\text { Tank 8 } \\
\text { Simulant }\end{array}$ & $\begin{array}{c}\text { Projected SB3 } \\
{[\mathbf{8}]}\end{array}$ \\
\hline $\mathrm{Al}$ & 11.8 & 11.02 \\
\hline $\mathrm{Ba}$ & 0.26 & 0.26 \\
\hline $\mathrm{Ca}$ & 2.82 & 2.96 \\
\hline $\mathrm{Ce}$ & $\mathrm{N} / \mathrm{A}$ & 0.34 \\
\hline $\mathrm{Cr}$ & 0.27 & 0.29 \\
\hline $\mathrm{Cu}$ & 0.17 & 0.18 \\
\hline $\mathrm{Fe}$ & 33.3 & 32.4 \\
\hline $\mathrm{K}$ & 0.01 & 0.41 \\
\hline $\mathrm{La}$ & $\mathrm{N} / \mathrm{A}$ & 0.20 \\
\hline $\mathrm{Mg}$ & 0.16 & 0.13 \\
\hline $\mathrm{Mn}$ & 3.24 & 6.40 \\
\hline $\mathrm{Na}$ & 7.58 & 9.08 \\
\hline $\mathrm{Ni}$ & 3.57 & 1.45 \\
\hline $\mathrm{Pb}$ & 0.12 & 0.32 \\
\hline $\mathrm{Si}$ & 1.12 & 1.13 \\
\hline $\mathrm{Zn}$ & 0.28 & 0.38 \\
\hline $\mathrm{Zr}$ & 0.47 & 0.66 \\
\hline * La was not added to the Tank 8 simulant. \\
\hline \multicolumn{2}{|c|}{} \\
\hline
\end{tabular}

The target sludge solids content was approximately $18.5 \mathrm{wt} \%$ air-dried total solids. Due to the additions of sodium oxalate, the total solids were adjusted using distilled water to match the nominal target. Acid additions were based on (1) total acid to achieve the acid stoichiometry and (2) acid mix to produce redox target $\left(0.2 \mathrm{Fe}^{2+} / \Sigma \mathrm{Fe}\right.$ redox ratio) by the modified redox correlation [9]. Concentrated formic acid (90-wt $\%)$ and nitric acid (50-wt $\%)$ were used during processing. After acid addition was completed, the temperatures of the slurries were ramped to boiling and remained at boiling for $\geq 12$ hours depending on the run. Slurry samples were pulled throughout the SRAT testing and at the end of testing to monitor cation solubility and oxalate concentrations.

In the low $\mathrm{pH}$ solubility testing, the SRAT products were adjusted to low $\mathrm{pH}$ levels to simulate upset conditions in DWPF that could indeed lower the $\mathrm{pH}$. An example would be transfer of a portion of the SRAT contents to the SMECT. The specific issue was the effect of lowering the $\mathrm{pH}$ on the solubility of Fe and of Gd during such an upset. Moving a large fraction of $\mathrm{Fe}$ to the supernate phase has the potential to remove a key neutron poison for the Pu from the insoluble solids.

The testing apparatus was the same as used during previous investigations for solubility testing [1]. In summary, the apparatus was a smaller version of the SRAT set-up. A temperature adjustable calibrated $\mathrm{pH}$ probe was used to monitor the $\mathrm{pH}$ throughout the testing and the experiment was conducted at $85^{\circ} \mathrm{C}$ to minimize evaporation losses. Throughout the testing, $\mathrm{pH}$ was adjusted using $\sim 10 \mathrm{M}$ nitric acid. The nitric acid was metered in until the $\mathrm{pH}$ reached approximately $6,5,4,3.5,3,2.5$, and 2 . The process was held near the target $\mathrm{pH}$ levels for 15 minutes to 2 hours depending on the test and the corresponding $\mathrm{pH}$. In some cases, additional acid was added to offset upward drift in the $\mathrm{pH}$ and to return the $\mathrm{pH}$ to the target value for that hold period. Usually, acid was added when the drift was greater than $0.1 \mathrm{pH}$ units.

Samples were taken upon stabilization at each $\mathrm{pH}$ level for supernate and solids analyses. Supernate samples were obtained by centrifuging a slurry sample and decanting the supernate fraction. For longer hold times at lower pH levels, additional samples were taken prior to dropping the $\mathrm{pH}$ to the next target. Solids samples were analyzed for weight percent total and dissolved solids, and weight percent soluble and insoluble fractions were determined based on this analysis. Density measurements were also performed on the slurry and supernate samples. A combination of sample results and material balance data permitted determination of the masses of supernate and insoluble solid phases throughout the test. This, combined with the compositional analysis, permitted the determination of the dissolved mass of $\mathrm{Fe}$ and $\mathrm{Gd}$. 


\subsection{ANALYTICAL METHODS}

As stated earlier, samples were generated throughout the runs and at the end of the runs for analyses to quantify the SRAT processing behavior. The SRAT samples were analyzed by the Savannah River Technology Center/Immobilization Technology Section Mobile Lab (SRTC-ML) to determine the chemical composition of the soluble and insoluble fractions. The SRAT product samples were prepared by calcining a portion of the samples at $900^{\circ} \mathrm{C}$ and then dissolving the calcined product using $\mathrm{Na}_{2} \mathrm{O}_{2} / \mathrm{NaOH}$ fusion, lithium metaborate fusion, and aqua regia dissolution. Cation analyses were performed using Inductively Coupled Plasma - Atomic Emission Spectroscopy (ICPAES). Anion analyses were performed using weighted dilutions and Ion Chromatography (IC). Supernate samples were obtained by centrifuging the slurry samples and removing the supernate. The SRAT product was also submitted for calcined, total, insoluble, and soluble wt $\%$ solids determinations. Total and dissolved solids were measured and insoluble and soluble solids were calculated based on the results. The dissolved cations and anions in the supernate were analyzed using ICP-AES and IC.

All analyses for this task were governed by Analytical Study Plan WSRC-RP-2002-00342 [10]. A sample request form accompanied each sample. A unique lab identification number was assigned to each sample for tracking purposes. Analyses were performed using approved analytical and QA procedures.

\subsection{RESULTS}

\subsection{SRAT Processing}

The main objective of the SRAT processing studies, as related to this task, was to monitor the solubility of $\mathrm{Fe}, \mathrm{Gd}$, and oxalate during and after completion of SRAT processing. This information will help DWPF determine if criticality will be an issue, especially with regards to formation of tris-oxalato iron complexes. Two levels of sodium oxalate were studied; 75\% (Run SB3-20) and 125\% (Run SB3-24) of the anticipated sodium oxalate in Tank 7. During the runs, hydrogen generation, foaming, slurry $\mathrm{pH}$, and nitrite destruction were also monitored to help determine the impact of oxalate on the process. However, data from the runs related to SRAT processing will be reported elsewhere.

The $125 \%$ sodium oxalate SRAT run (Run SB3-24) had poor nitrite destruction. While this is important from a SRAT processing perspective, the main goal of the testing was to produce product for the lower $\mathrm{pH}$ testing and this level of sodium oxalate would not expected to be processed in the DWPF. While insight provided into Fe solubility during processing is beneficial, results of previous testing have shown that the lower $\mathrm{pH}$ studies result in more Fe becoming soluble [1]. Therefore, even though the SRAT processing goal was not met, insight into solubility was provided.

As mentioned earlier, samples were taken throughout the runs for supernate cation and anion analysis. Table A1 in Appendix A presents the results from the analyses of the supernate samples. Table A1 indicates the sample IDs, the time the samples were taken relative to the end of acid addition, and the $\mathrm{pH}$ of the SRAT slurry at the time of sampling. Table 2 contains the $\mathrm{Fe}$ and $\mathrm{Gd}$ supernate data from the runs. In this table, data is reported as the fraction of the total available Fe and Gd dissolved. The values were obtained as follows:

1. The analyzed Fe concentration in the supernate was divided by the density of the supernate to give the amount of Fe in the supernate.

2. The grams of supernate in the sampled SRAT slurry were calculated based on the insoluble solids concentration in the SRAT product and the mass of slurry available at the time of sampling.

3. The grams of supernate were multiplied by the result from step 1 to give the total grams of soluble Fe.

4. The grams of $\mathrm{Fe}$ available for dissolving were calculated by multiplying the mass of slurry available at the time of sampling by the total (dried) solids of the SRAT product and the Fe concentration in the total (dried) solids from the SRAT product.

5. The ratio of dissolved Fe was then calculated based on the grams of soluble Fe (step 3) divided by the total grams of Fe available (step 4).

The same method was followed for calculating the amount of Gd dissolved. 
Table 2 - Fraction of Fe and Gd Dissolved during SRAT Processing

\begin{tabular}{|c|c|c|c|c|c|c|}
\hline \multirow{5}{*}{$\begin{array}{c}75 \% \\
\text { Sodium } \\
\text { Oxalate } \\
\text { Run } \\
\text { (SB3-20) }\end{array}$} & Sample ID & ICP-0 & ICP-5 & ICP-9 & ICP-15 & Product $^{2}$ \\
\hline & Time $(\min )^{1}$ & 14 & 362 & 602 & 1023 & N/A \\
\hline & $\mathrm{pH}$ & 4.31 & 4.72 & 4.75 & 4.80 & 4.80 \\
\hline & $\begin{array}{c}\text { Fraction Fe } \\
\text { Dissolved }\end{array}$ & 4.91E-02 & $2.15 \mathrm{E}-02$ & $1.87 \mathrm{E}-02$ & $1.70 \mathrm{E}-02$ & $1.35 \mathrm{E}-02$ \\
\hline & $\begin{array}{c}\text { Fraction Gd } \\
\text { Dissolved }\end{array}$ & $3.12 \mathrm{E}-02$ & 2.84E-02 & 2.74E-02 & 2.97E-02 & $1.70 \mathrm{E}-02$ \\
\hline \multirow{5}{*}{$\begin{array}{c}125 \% \\
\text { Sodium } \\
\text { Oxalate } \\
\text { Run } \\
(\mathrm{SB3}-24)\end{array}$} & Sample ID & ICP-0 & ICP-2 & ICP-8 & ICP-11 & Product $^{2}$ \\
\hline & Time $(\min )^{1}$ & 7 & 184 & 541 & 745 & N/A \\
\hline & pH & 6.60 & 6.93 & 7.05 & 7.08 & 7.08 \\
\hline & $\begin{array}{c}\text { Fraction Fe } \\
\text { Dissolved }\end{array}$ & 4.37E-02 & $4.52 \mathrm{E}-03$ & $2.31 \mathrm{E}-03$ & $1.78 \mathrm{E}-03$ & $1.52 \mathrm{E}-03$ \\
\hline & $\begin{array}{c}\text { Fraction Gd } \\
\text { Dissolved }\end{array}$ & 0.875 & 1.06 & 1.07 & 1.04 & 0.801 \\
\hline
\end{tabular}

The solubility of Fe and Gd were both affected by the amount of sodium oxalate present in the feed. In both cases, the "Product" samples, which were taken after the SRAT product cooled to room temperature, contained less soluble Fe and Gd than samples taken at the end of the SRAT process while the contents were at boiling. This was consistent with the results of earlier testing [1]. Fe appeared to be more soluble during the testing with $75 \%$, whereas Gd was much more soluble during the testing with $125 \%$ sodium oxalate. The higher Fe in the $75 \%$ case could be an artifact of the lower $\mathrm{pH}$ seen during the 75\% SRAT run, but the low $\mathrm{pH}$ solubility testing will provide more insight since $\mathrm{pH}$ levels were specifically targeted. It should be noted that SRAT product results were used to determine the total amounts of $\mathrm{Fe}$ and Gd available in the feed. For the $125 \%$ sodium oxalate product, detected Gd was $~ 35 \%$ (or $\sim 0.006 \%$ wt $\%$ ) of what was found in the $75 \%$ sodium oxalate product (or $\sim 0.016 \mathrm{wt} \%$ ). However, the actual amount added to the $125 \%$ sodium oxalate feed was $\sim 80 \%$ of that added to the $75 \%$ sodium oxalate feed. Therefore, some error in the total amount of Gd available exists for the $125 \%$ case, and the results provided for the fraction of Gd dissolved would therefore be conservative. When only the amount of $\mathrm{Gd}$ in the supernate is compared for both runs versus the fraction of $\mathrm{Gd}$ dissolved (which takes into account the amount of Gd detected in the product), the numbers are only 10x higher for the soluble Gd in the $125 \%$ case versus the $\sim 25$ to 50x higher reported in Table 2 . In any case, the amounts of Gd dissolved were much higher in the $125 \%$ run. Both of these tests indicate that higher levels of Fe can be dissolved when higher levels of sodium oxalate are present (see reference [1] for 50\% and $25 \%$ sodium oxalate cases). For Gd, comparable results were seen for the $75 \%$ sodium oxalate test and the previously tested $50 \%$ sodium oxalate test [1]. However, the $125 \%$ sodium oxalate test had much higher dissolved Gd. In the previous tests, SRAT processing with $25 \%$ sodium oxalate resulted in no Fe or Gd being dissolved within the detection limits [1].

The fractions of Fe and Gd dissolved during SRAT processing are shown in Figures 1 and 2. Product data is also shown in the figures. For clarity, the product data is arbitrarily represented as +10 minutes to the last sample pulled during processing. Corresponding $\mathrm{pH}$ plots for the runs are given in Appendix B as Figure B1. Figure 1 shows that the largest amount of $\mathrm{Fe}$ was dissolved when the SRAT process was at the minimum $\mathrm{pH}$ (i.e., the end of acid addition). After this, the fraction of Fe dissolved drastically decreased and remained relatively low to the end of the run. For Gd, the dissolved Gd remained relatively constant after acid addition for the $75 \%$ sodium oxalate run. In the $125 \%$ run, $\mathrm{Gd}$ continued to dissolve after the end of acid addition. After concentration was completed, the level remained the same until the test was completed. 
Figure 1 - Fraction of Fe Dissolved during SRAT Processing

$\checkmark 75 \%$ Sodium Oxalate Test $125 \%$ Sodium Oxalate Test

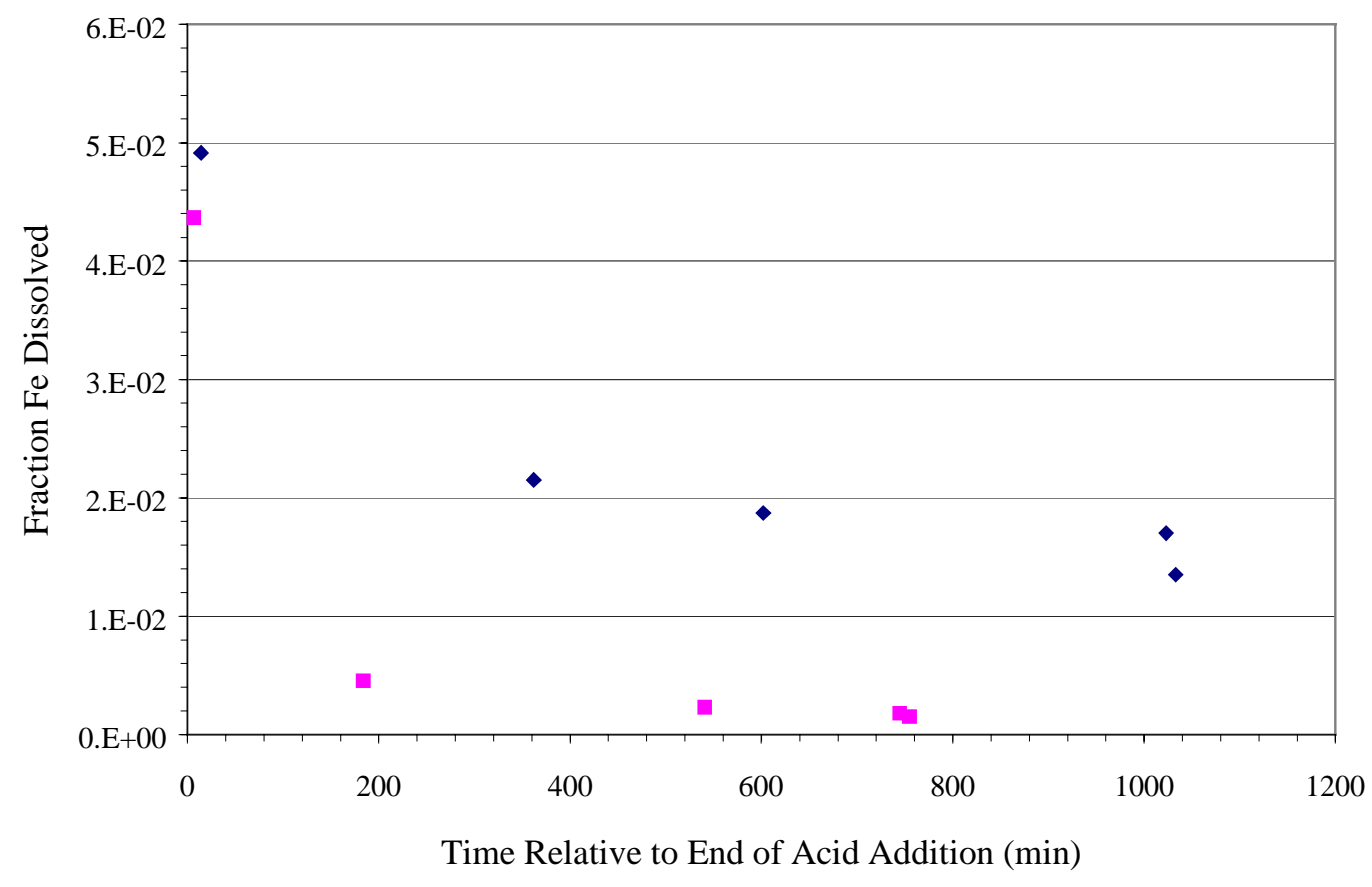

Figure 2 - Fraction of Gd Dissolved during SRAT Processing

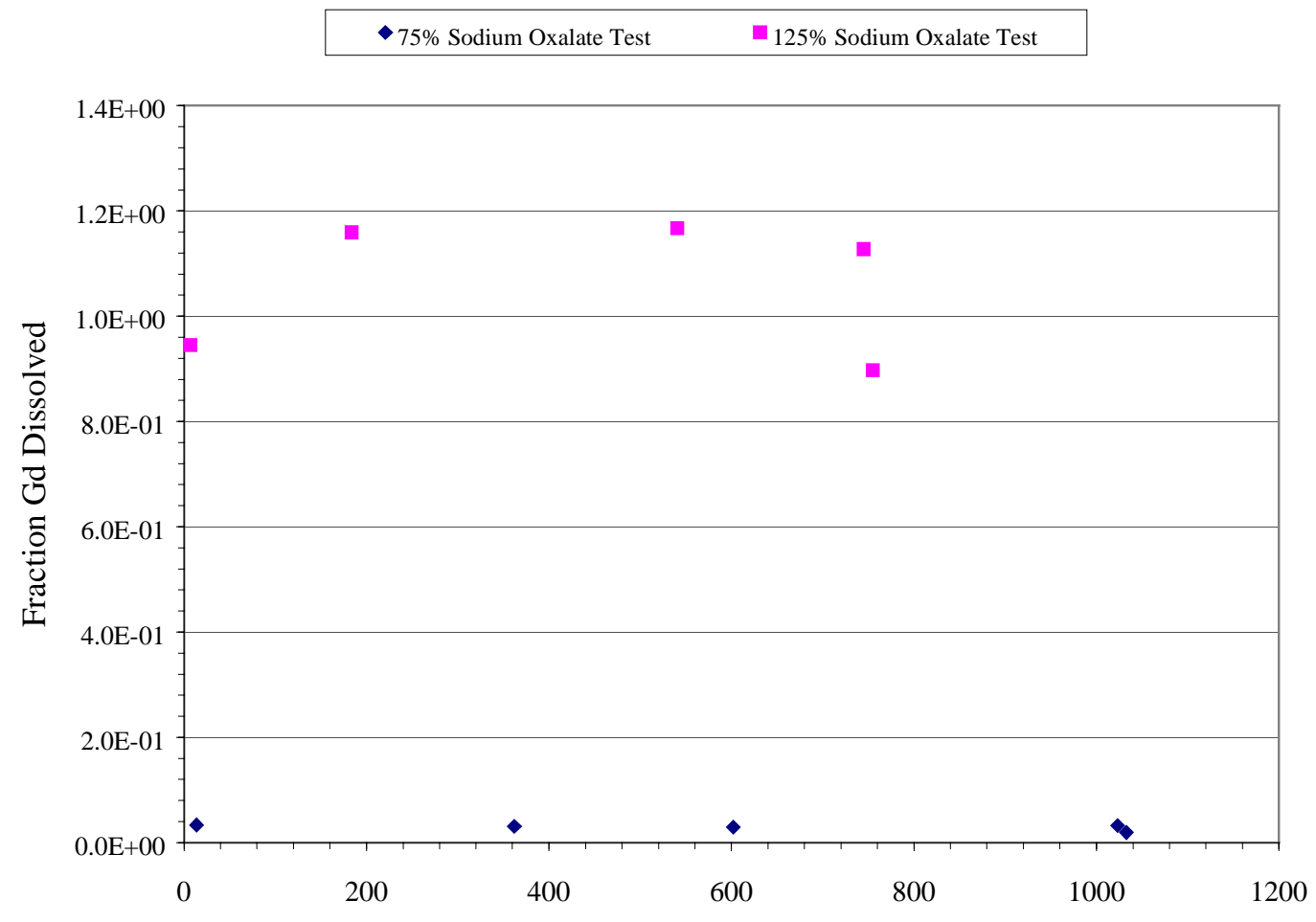

Time Relative to End of Acid Addition (min) 
The anion samples during the runs and the SRAT products were analyzed for oxalate concentration. Samples during the runs were the same as the ones used for cation analyses so they were centrifuged and decanted. The product samples, on the other hand, were analyzed using a weighted dilution. These samples were adjusted for density to compare to the in-process samples. The oxalate concentrations are given in Table 3. During the SRAT process, samples indicate that $>50 \%$ of the oxalate added was in the supernate for the 75\% SRAT run, while $>80 \%$ of the oxalate added was in the supernate for the $125 \%$ SRAT run. About $85 \%$ of the oxalate was detected in the $75 \%$ SRAT run product, while almost all of the oxalate added was detected in the $125 \%$ SRAT run product.

Table 3 - Oxalate Concentration in Supernate Samples from SRAT Processing

\begin{tabular}{|c|c|c|c|c|c|c|}
\hline \multirow{4}{*}{$\begin{array}{l}75 \% \text { Sodium } \\
\text { Oxalate Run } \\
\text { (SB3-20) }\end{array}$} & $\begin{array}{c}\text { Sample } \\
\text { ID }\end{array}$ & ICP-0 & ICP-5 & ICP-9 & ICP-15 & Product $^{2}$ \\
\hline & $\begin{array}{c}\text { Time } \\
(\min )^{1}\end{array}$ & 14 & 362 & 602 & 1023 & N/A \\
\hline & pH & 4.31 & 4.72 & 4.75 & 4.80 & 4.80 \\
\hline & $\begin{array}{c}\text { Oxalate } \\
(\mathrm{mg} / \mathrm{L})\end{array}$ & 26,600 & 33,200 & 33,300 & 33,000 & 46,995 \\
\hline \multirow{4}{*}{$\begin{array}{c}125 \% \text { Sodium } \\
\text { Oxalate Run } \\
(\text { SB3-24) }\end{array}$} & $\begin{array}{c}\text { Sample } \\
\text { ID }\end{array}$ & ICP-0 & ICP-2 & ICP-8 & ICP-11 & Product $^{2}$ \\
\hline & $\begin{array}{c}\text { Time } \\
(\mathrm{min})^{1}\end{array}$ & 7 & 184 & 541 & 745 & N/A \\
\hline & pH & 6.60 & 6.93 & 7.05 & 7.08 & 7.08 \\
\hline & $\begin{array}{c}\text { Oxalate } \\
\text { (mg/L) }\end{array}$ & 62,400 & 78,500 & 71,500 & 70,000 & 68,320 \\
\hline
\end{tabular}

\subsection{Low pH Studies}

Two $\mathrm{pH}$ adjustment tests were performed to determine fractions of $\mathrm{Fe}$ and $\mathrm{Gd}$ dissolved at low $\mathrm{pH}$ values as might be experienced if some of the SRAT material were inadvertently transferred to the SMECT. One used the 75\% sodium oxalate SRAT product (Run SB3-20); the other used the 125\% sodium oxalate SRAT product (Run SB3-24).

As described in Section 3 and in WSRC-TR-2002-00322 [1], the SRAT products were heated to $85^{\circ} \mathrm{C}$ with a goal of adjusting the $\mathrm{pH}$ to a target of $\sim 2$ by adding additional nitric acid. During the process, samples were taken at each $\mathrm{pH}$ level, along with additional samples at some of the $\mathrm{pH}$ levels to account for upward drift in the $\mathrm{pH}$. These samples were analyzed to determine the soluble species at the $\mathrm{pH}$ levels and throughout the testing. The amounts of soluble $\mathrm{Fe}$ and $\mathrm{Gd}$ for each sample were then used to determine the fraction of Fe and Gd soluble. The same methodology used to calculate the fractions during SRAT processing were used to perform these calculations. However, total solids and insoluble solids data was available on each sample taken throughout the lower $\mathrm{pH}$ testing. Table 4 contains the percent of $\mathrm{Fe}$ and $\mathrm{Gd}$ dissolved as the $\mathrm{pH}$ was lowered to 2 and with respect to time. Supernate results for all elements analyzed are given as Tables A2 and A3 of Appendix A. Once again, the Gd percentage fractions are a little high because of the low amount of $\mathrm{Gd}$ found in the $125 \%$ sodium oxalate SRAT product. In general, more uncertainty exists in the $\mathrm{Gd}$ values for fraction dissolved than for $\mathrm{Fe}$, because of the lower $\mathrm{Gd}$ concentrations being measured. Figures 3 and 4 show the percent of $\mathrm{Fe}$ and $\mathrm{Gd}$, respectively, dissolved versus the test $\mathrm{pH}$.

In general, the percent total Fe dissolved increased as $\mathrm{pH}$ decreased for both products. In the $125 \%$ sodium oxalate test, a large amount of $\mathrm{Gd}$ was dissolved at the beginning of the test. This is likely due to the higher starting $\mathrm{pH}$ (i.e., 7 ) and the solubility of $\mathrm{Gd}$ at this $\mathrm{pH}$. The amount of $\mathrm{Fe}$ and $\mathrm{Gd}$ in solution at each $\mathrm{pH}$ level changed with time in both tests; however the trend was not consistent between runs or with the specific element. The changes with time at the $\mathrm{pH}$ levels may indicate that equilibrium was not completely achieved between the insoluble solids and the supernate. 
Table 4 - Percentage Fraction of Fe and Gd Dissolved in Low pH Testing at $85^{\circ} \mathrm{C}$

\begin{tabular}{|c|c|c|c|c|c|c|c|}
\hline \multicolumn{3}{|c|}{$\mathbf{7 5 \%}$ Sodium Oxalate (SB3-20 Product) } & \multicolumn{3}{|c|}{ 125\% Sodium Oxalate (SB3-24 Product) } \\
\hline $\begin{array}{c}\text { Elapsed } \\
\text { Time } \\
(\mathbf{m i n})\end{array}$ & $\mathbf{p H}$ & $\begin{array}{c}\text { \% Total } \\
\text { Fe } \\
\text { Dissolved }\end{array}$ & $\begin{array}{c}\text { \% Total } \\
\text { Gd } \\
\text { Dissolved }\end{array}$ & $\begin{array}{c}\text { Elapsed } \\
\text { Time } \\
(\mathbf{m i n})\end{array}$ & $\mathbf{p H}$ & $\begin{array}{c}\text { \% Total } \\
\mathbf{F e} \\
\text { Dissolved }\end{array}$ & $\begin{array}{c}\text { \% Total } \\
\text { Gd } \\
\text { Dissolved }\end{array}$ \\
\hline 0 & 4.66 & 1.25 & 1.56 & 0 & 7.00 & 0.178 & 70.9 \\
\hline 48 & 3.99 & 2.62 & 4.40 & 21 & 6.11 & 4.16 & 86.4 \\
\hline 73 & 3.49 & 4.06 & 7.28 & 40 & 5.04 & 9.49 & 20.1 \\
\hline 100 & 2.99 & 5.94 & 13.3 & 67 & 4.01 & 11.40 & 6.74 \\
\hline 130 & 3.05 & 5.60 & 16.6 & 89 & 3.58 & 13.47 & 7.65 \\
\hline 142 & 2.41 & 7.24 & 32.4 & 112 & 3.07 & 13.33 & 23.0 \\
\hline 171 & 2.55 & 8.19 & 32.9 & 137 & 3.02 & 13.58 & 25.9 \\
\hline 185 & 1.99 & 9.75 & 49.9 & 152 & 2.65 & 13.86 & 41.3 \\
\hline 245 & 1.99 & 7.84 & 56.2 & 167 & 2.58 & 14.25 & 47.9 \\
\hline 305 & 2.03 & 6.11 & 49.4 & 187 & 2.06 & 15.68 & 87.0 \\
\hline & & & & 229 & 2.15 & 14.33 & 106 \\
\hline & & & & 261 & 2.03 & 13.40 & 103 \\
\hline
\end{tabular}

Figure 3 - Iron Dissolution with pH Adjustment

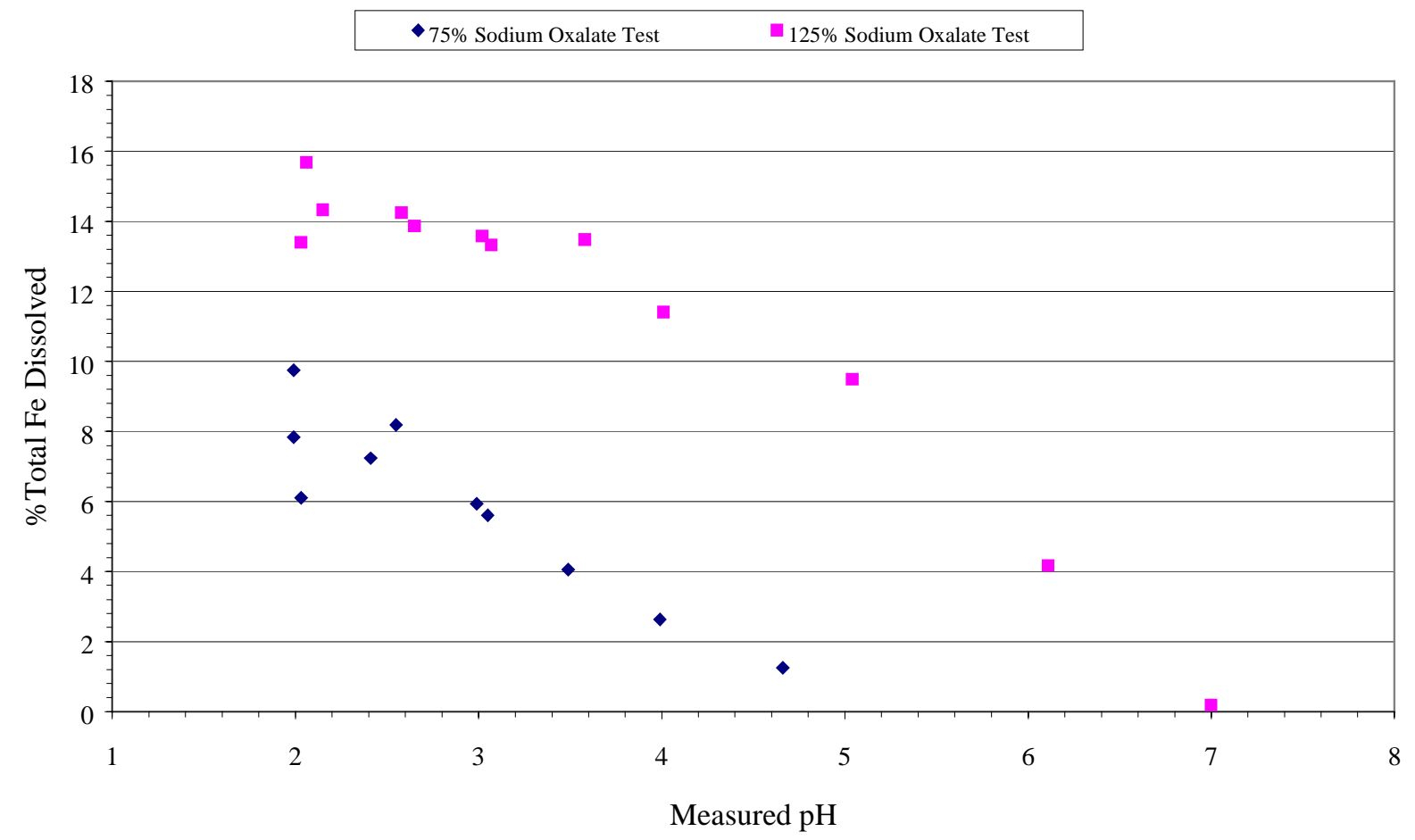


Figure 4 - Gadolinium Dissolution with pH Adjustment

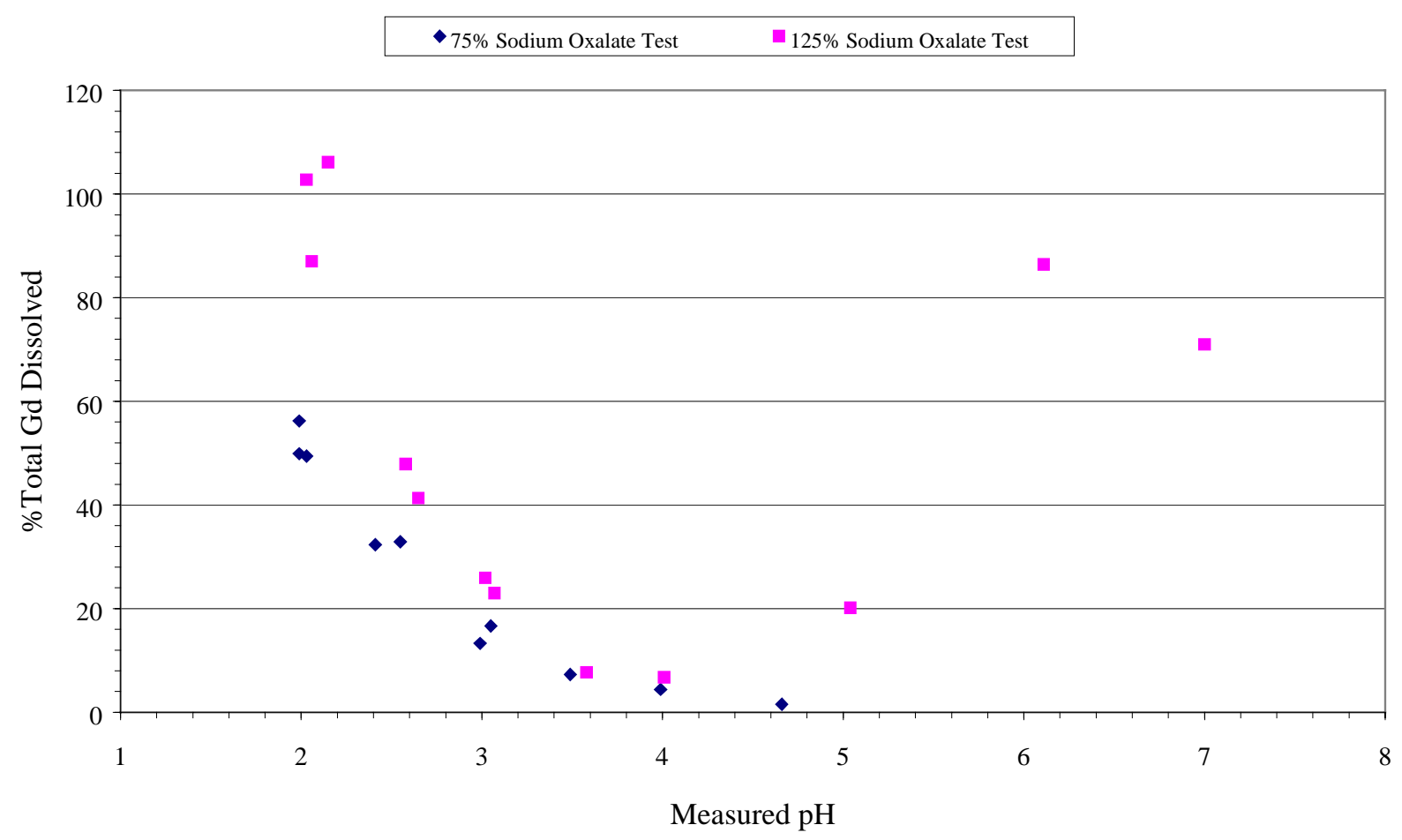

The lower $\mathrm{pH}$ testing showed that the amounts of dissolved Fe remained relatively small. Overall, the maximum $\mathrm{Fe}$ dissolved in the $75 \%$ sodium oxalate containing feed was $\sim 10 \%$, while it was $\sim 16 \%$ for the $125 \%$ sodium oxalate containing feed. Gadolinium continued to dissolve during this test with higher concentrations in the slurry with higher levels of sodium oxalate. The maximum Gd dissolved was $\sim 56 \%$ for the $75 \%$ sodium oxalate test and was $\sim 100 \%$ for the $125 \%$ sodium oxalate test. These bounding tests showed that slightly more Fe can become soluble at higher sodium oxalate concentrations; however, $\sim 84 \%$ of the Fe still remained in the solids. For Gd, the $75 \%$ sodium oxalate case produced similar results to those seen in the $50 \%$ sodium oxalate testing [1], whereas the results for the $125 \%$ sodium oxalate case were much greater than those seen in the other tests. Once again, this may be an artifact of the relatively low Gd number obtained in the analyses of the SRAT product. When only the amount of soluble Gd is considered (i.e., the amount available for dissolving is not considered), the amounts of soluble Gd were comparable between the runs. If the product actually contained all that was added to the SRAT feed, then the percentage of Gd dissolved would be closer to the results from the other tests. Literature data indicates that $\mathrm{Fe}$ and $\mathrm{Pu}$ (IV) have similar solubilities in weak nitric acid solutions, and therefore $\mathrm{Fe}$ and $\mathrm{Pu}$ would not be separately dissolved over the $\mathrm{pH}$ range of 0 to 4 [11].

\subsection{CONCLUSIONS}

Bounding testing for Fe and Gd solubility has been completed for $75 \%$ and $125 \%$ of the anticipated sodium oxalate level in Tank 7. During SRAT processing, the maximum Fe fraction that became soluble was $4.91 \times 10^{-2}$ for the $75 \%$ sodium oxalate test and $4.37 \times 10^{-2}$ for the $125 \%$ sodium oxalate test. $\mathrm{Gd}$, on the other hand, had a maximum soluble fraction of $3.12 \times 10^{-2}$ for the $75 \%$ sodium oxalate test and 1.07 for the $125 \%$ sodium oxalate test. For the lower $\mathrm{pH}$ solubility testing, the amounts of $\mathrm{Fe}$ and $\mathrm{Gd}$ that became soluble increased at the lower $\mathrm{pH}$ levels tested. Iron present in the supernate still represented a small portion of the total amount in the sludge, whereas Gd concentration was more significant. The maximum amount of Fe was dissolved with the $125 \%$ sodium oxalate product and was $\sim 16 \%$, and the highest Gd was also dissolved with the $125 \%$ sodium oxalate product and was $\sim 100 \%$. It should be noted that the $\mathrm{Gd}$ fractions and percentages dissolved for the $125 \%$ sodium oxalate testing are conservatively high because of the relatively small amount of Gd detected in the SRAT product. This number was used to calculate the total Gd available 
and was about a fourth of what it was anticipated to be based on the amount added. Therefore, the fraction of Gd dissolved could be up to a fourth lower.

\subsection{REFERENCES}

[1] C.C. Herman, D.C. Koopman, N.E. Bibler, D.R. Best, and M.F. Williams, "SRAT Processing of Sludge Batch 3 Simulant to Evaluate Impacts of H-Canyon Slurry Containing Precipitated Pu and Gd", WSRCTR-2002-00322, July 25, 2002.

[2] T.L. Fellinger, D.T. Hobbs, M.G. Bronikowski, B.C. Hill, and J.H. Gray, "Demonstrations of the Tank Farm Washing Process and the DWPF SRAT Cycle with Sludge Batch 3 Simulant and Precipitated Pu/Gd Mixture from H-Canyon Tank 18.3", WSRC-TR-2002-00208, May 8, 2002.

[3] C.C. Herman, D.R. Best, T.B. Edwards, J.G. George, D.C. Koopman, and M.F. Williams, "Data Summary from Sludge Batch 3 Simulant SRAT Runs to Evaluate Impacts of Noble Metals Mass and Coal Size, Mass, and Treatment", SRT-GPD-2002-00121, October 31, 2002.

[4] C.C. Herman, "Task Technical and QA Plan: Oxalate Studies for Sludge Batch 3 - SRAT Processing", WSRC-RP-2002-00320, June 3, 2002.

[5] A.Q. Goslen, "Estimated Sodium Oxalate in the Tank Farm", March 22, 1984.

[6] D.C. Koopman, "Sludge Batch 3 - Run 20, Initial Run with 75\% Residual Oxalate", SRT-GPD-200200116, September 12, 2002.

[7] D.C. Koopman, "Sludge Batch 3 - Run 24, SRAT Run with 125\% Residual Oxalate", SRT-GPD-200200120, September 26, 2002.

[8] N.E. Bibler, D.K. Peeler, and T.B. Edwards, "An Assessment of the Impacts of Adding Am/Cm and Pu/Gd Waste Streams to Sludge Batch 3 (SB3) on DWPF $\mathrm{H}_{2}$ Generation Rates and Glass Properties", WSRCTR-2002-00145, March 22, 2002.

[9] C.M. Jantzen and J.B. Pickett, "Preliminary Redox Model for DWPF Sludge Batch 3", WSRC-TR-200200332, May 9, 2002.

[10] C.C. Herman, "Analytical Study Plan: Oxalate Studies for Sludge Batch 3 - SRAT Processing", WSRCRP-2002-00342, June 19, 2002.

[11] D.G. Karraker, "Solubility of Uranium, Plutonium, Iron, and Manganese in Weak Nitric Acid and Oxalic Acid Solutions: A Literature Survey", WSRC-RP-98-00091, March 5, 1998.

\subsection{ACKNOWLEDGEMENTS}

The authors would like to acknowledge the following personnel and groups for their assistance in performing the studies and analyzing the required samples:

- D.C. Koopman for providing the acid calculations and run plans for the SRAT runs.

- M.F. Williams for coordinating and assisting with the SRAT runs and low pH testing.

- T.O. Burckhalter, J.W. Duvall, M.L. Moss, S.O. King, and V.J. Williams for performing the SRAT runs and the low $\mathrm{pH}$ testing.

- D.J. Pittman and P.A. Toole for providing assistance with the analyses.

- V.J. Williams for analyzing the solids and densities on the low $\mathrm{pH}$ samples. 
Westinghouse Savannah River Company

Savannah River Technology Center
WSRC-TR-2002-00508

Revision: 0 November 15, 2002

Appendix A - Supernate Analyses from $75 \%$ and 125\% Sodium Oxalate Testing 


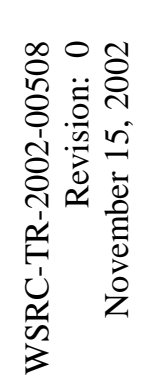

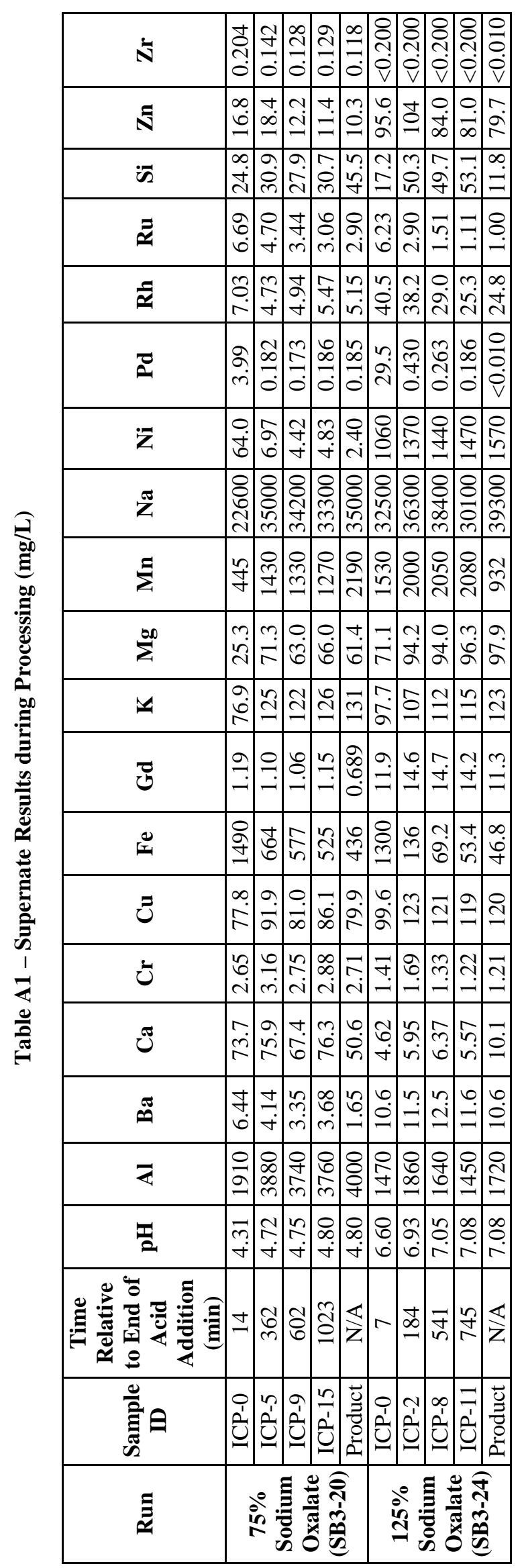




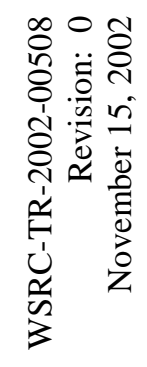

产

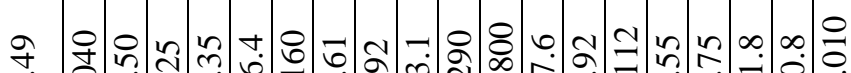

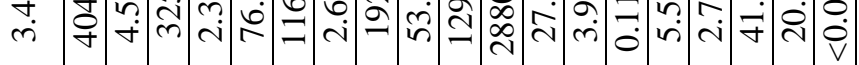
๙ે

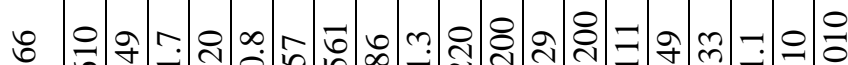

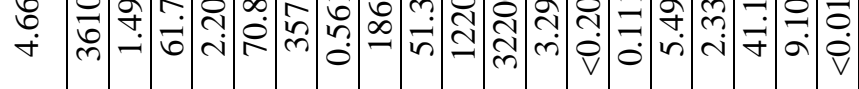

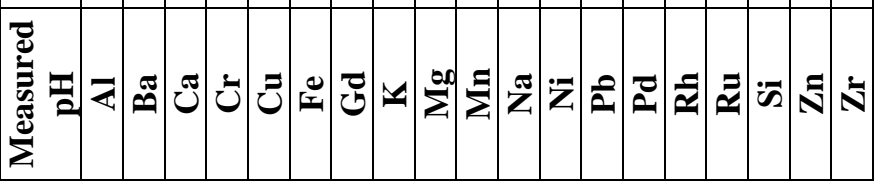




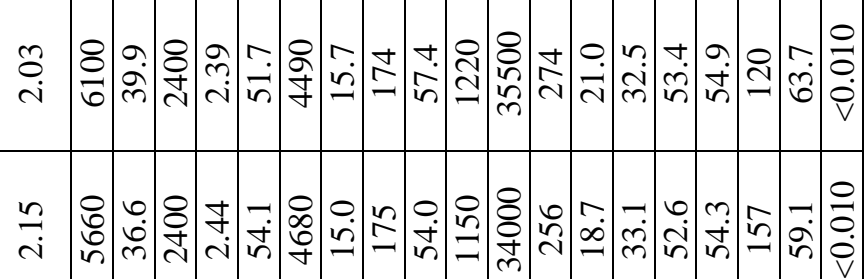

อิ

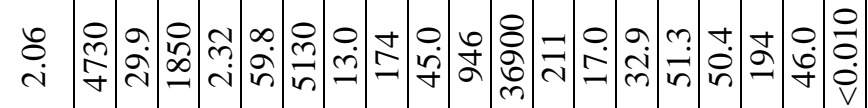

ֻ.

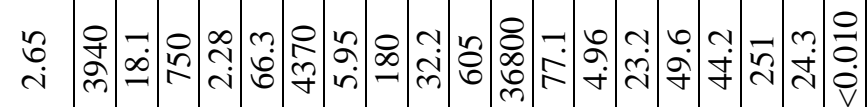

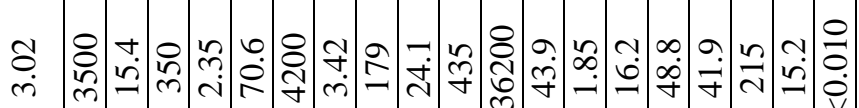

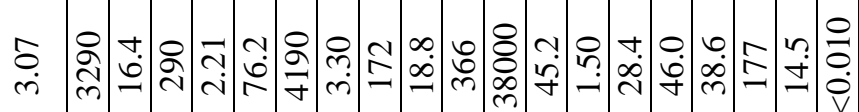

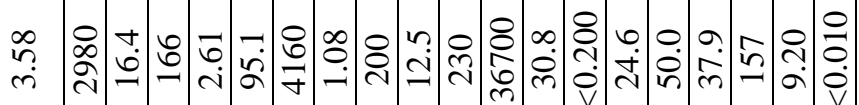

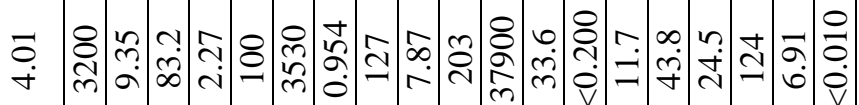

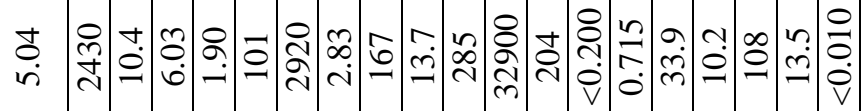

芯

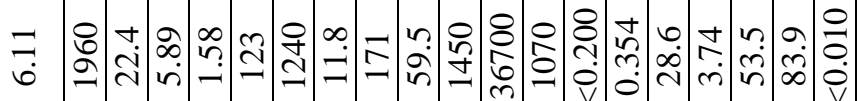

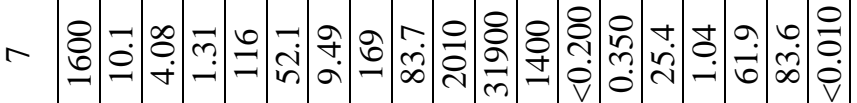

ग

ते

졿

氜

空

范

음 
Westinghouse Savannah River Company

Savannah River Technology Center
WSRC-TR-2002-00508

Revision: 0

November 15, 2002

Appendix B - pH Plot for SRAT Processing 
Figure B1 - pH Plots for SRAT Runs containing $75 \%$ and $125 \%$ Sodium Oxalate

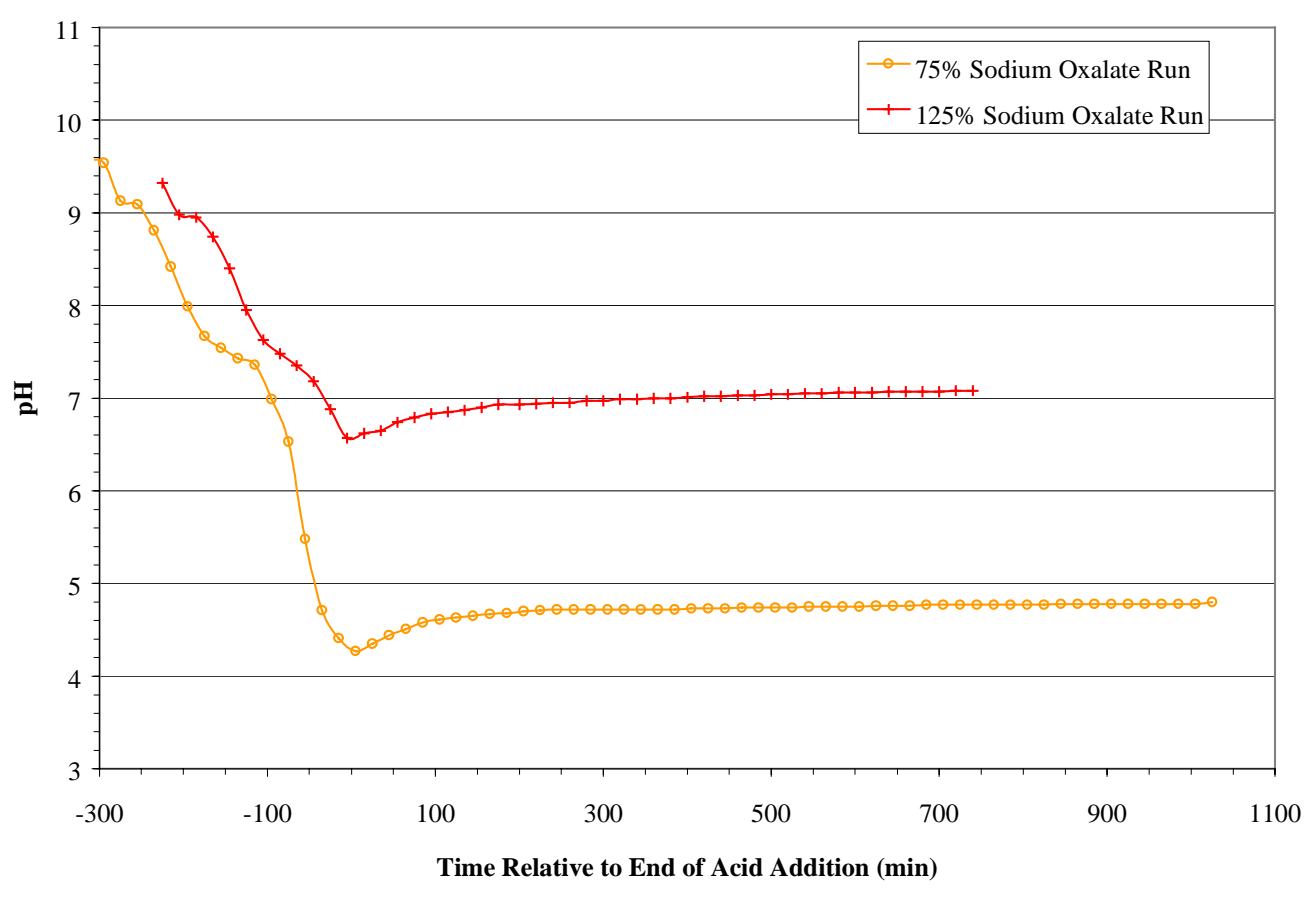

